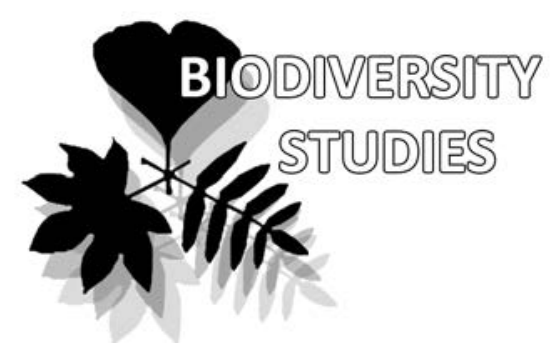

Marina N. Koldaeva ${ }^{1}$

e-mail: layekujjwal@yahoo.co.in

Valentina A. Kalinkina ${ }^{1,2 *}$

e-mail: ksubaikundu@gmail.com

Galina F. Darman

e-mail: prakashbot1973@gmail.com

${ }^{1}$ Botanical Garden-Institute FEB RAS,

Vladivostok, Russia

${ }^{2}$ Far Eastern Federal University,

Vladivostok, Russia

${ }^{3}$ Amur Branch of the Botanical GardenInstitute FEB RAS, Blagoveschensk, Russia

* corresponding author

Manuscript received: 20.03.2019

Review completed: 05.10.2020

Accepted for publication: 25.12.2020

Published online: 10.01.2021

\section{The first record of Melilotoides schischkinii (Fabaceae) from Amur Region, Russia}

\author{
Marina N. Koldaeva ${ }^{1}$, Valentina A. Kalinkina ${ }^{1,2}$, , Galina F. Darman ${ }^{3}$
}

\begin{abstract}
A B S T R A C T
Information about a new locality of Melilotoides schischkinii (Vassilcz.) Soják (Fabaceae), a rare endemic to Amur Region, is provided in the article. The habitat of the plant and the status of its population in the region are described. The new locality is remote from the known range of the species, which significantly expands its distribution.
\end{abstract}

K e y w o r d s : Melilotoides schischkinii, Fabaceae, new finding, rare species, endemic, Amur Region

\section{P E 3 Ю M E}

Кодааева М.Н., Калинкина В.А., Аарман Г.Ф. Первая находка Melilotoides schischkinii (Fabaceae) в Амурской области, Россия. Приведены сведения о новом местонахожАении реАкого эндемичного представитеАя сем. Fabaceae - Melilotoides schischkinii (Vassilcz.) Soják. Охарактеризовано местообитание виАа и состояние популяции на территории Амурской области. Новое местонахождение значительно удалено от естественного ареала виАа, что существенно расширяет его распространение.

КАючевые слова: Melilotoides schischkinii, Fabaceae, находка, редкий виА, эндемик, Амурская область
According to the latest revisions of the Far Eastern flora (Pavlova 1989, 2006), two species of the genus Melilotoides Heist. ex Fabr. are found in the Russian Far East: M. ruthenica (L.) Soják and M. schischkinii (Vassilcz.) Soják. M. ruthenica was first described by C. Linaeus in 1753 under the name Trigonella ruthenica (Linnaei 1753: 776). At different times, the species was placed in the genera Medicago L. (Ledebour 1842), Melissitus Medik. (Lachashvili 1958), Turukhania Vassilcz. (Pavlova 1989), and Melilotoides (Cherepanov 1995). For the Russian Far East, this species was first reported by Komarov \& Klobukova-Alisova (1932) in the 'Key to the plants of the Eastern Region of the USSR' under the name Medicago ruthenica Ldb., which is a synonym to the Linnean species Trigonella ruthenica. Grossheim (1945) indicated that the species Medicago ruthenica from the Far East did not match the latter in traits, and he related the Far Eastern soecimens of "Medicago ruthenica" to the new species, Trigonella korshinskyi Grossh., endemic to the rocky slopes of the Zeya-Bureya region (Grossheim 1945). This decision was not supported by Pavlova $(1989,2006)$. Based on the significant morphological similarity and the overlap of their distribution ranges, Pavlova suggested Trigonella korshinskyi to be conspecific to Melilotoides ruthenica, and placed the name Trigonella korshinskyi as a synonym of the latter species (Pavlova 1989). Analysis the characters of the species, including those listed in the table (Table 1), supports this statement.
The species Melilotoides schischkinii was first mentioned for the Russian Far East also in the 'Key to plants of the Far Eastern Region of the USSR' (Komarov \& KlobukovaAlisova 1932), but under the erroneous name Medicago platycarpos Ledeb. The latter has a great resemblance with $\mathrm{Me}$ lilotoides schischkinii in size and shape of fruit, a character that distinguishes this species from other Far Eastern plants of the genus. The species independence of the authentic Far Eastern specimens was later confirmed by Vassilchenko (1951), who also described this plant under the name Trigonella schischkinii Vassilcz. The species was re-described by Voroschilov (1966) as Medicago vassilczenkoi Worosch. Subsequently, the priority name of the species underwent the same nomenclature changes as those noted above for Melilotoides ruthenica (Lachashvili 1958, Pavlova 1989, 2006, Cherepanov 1995).

The current range of $M$. ruthenica occupies the European part of Russia, the Caucasus, Siberia, and the eastern part of Amur Region (Pavlova 1989); M. schischkinii is endemic to the Sikhote-Alin mountain range (Pavlova 1989).

During a trip to the vicinities of the Bureyskaya Hydroelectric Power Plant (HPP) in September 2018, we found several specimens of the genus Melilotoides on the right bank of the Bureya River (Fig. 1, 2).

We compared the collected specimen with the original description and with related species whose ranges overlap (Table 1) and came to the conclusion that the finding should 
Table 1. Comparative characteristics of three Melilotoides species and specimen found in new locality

\begin{tabular}{|c|c|c|c|c|}
\hline Taxonomic character & M. korshinskyi & M. rutbenica & M. schischkinii & Specimen analyzed \\
\hline Corolla length, mm & $5-6^{*}$ & $5-6^{*}$ & $\begin{array}{l}5-8^{*} \\
(5) 6-8(9)^{* *}\end{array}$ & - \\
\hline $\begin{array}{l}\text { Color of corolla of live } \\
\text { petals }\end{array}$ & yellow with purple veins & yellow or almost purple & \multicolumn{2}{|l|}{$\begin{array}{l}\text { yellow with purple veins in - } \\
\text { the middle of vexillum }\end{array}$} \\
\hline Corolla color in herbarium & turning blue & turning blue & $\begin{array}{l}\text { from yellow to orange- } \\
\text { yellow }\end{array}$ & - \\
\hline $\begin{array}{l}\text { Number of flowers per } \\
\text { inflorescence }\end{array}$ & $3-4 *$ & $4-8(10)^{*}$ & $\begin{array}{l}8-10(12)^{*} \\
5-10^{* *}\end{array}$ & $7-8^{* *}$ \\
\hline $\begin{array}{l}\text { Inflorescence type and } \\
\text { raceme density }\end{array}$ & \multicolumn{2}{|c|}{$\begin{array}{c}\text { raceme, more or less dense umbel-like raceme, more } \\
\text { or less dense }\end{array}$} & umbel-like raceme, loose & umbel-like loose raceme \\
\hline Fruit length, mm & $11-12 *$ & $\begin{array}{l}5-8(12)^{*} \\
8-10(12)^{* *}\end{array}$ & $\begin{array}{l}(8) 10-15(18)^{*} \\
(10-12) 15-20^{* *}\end{array}$ & $18-22(24)^{* *}$ \\
\hline Fruit width, mm & $4 *$ & ${ }_{4-5^{* *}}^{(2)} 5^{*}$ & ${ }_{5-6^{* *}}^{(5)} 6-8(10)^{*}$ & $8-9 * *$ \\
\hline
\end{tabular}

* Published data (Grossheim 1945, Pavlova 1989); ** authors' data

be identified as $M$. schischkinii based on such characters as the fruit size and the rostrum position.

Until recently, $M$. schischkinii has been known only from Primorye Territory (Pavlova 1989, 2006), where the localities of the species are confined to the southern and eastern macroslopes of the mountain system Sikhote-Alin (Fig. 2). The northernmost habitats of M. schischkinii in Primorsky Krai are located in the interfluve between the Malaya Kema and the Velikaya Kema rivers (Terney District), north of the Sikhote-Alin State Nature Biosphere Reserve. There are no collections of this plant from the territory of the reserve (Pimenova 2016). Recently, M. schischkinii has been collected by Kryukova (2013, p. 151) in the valley of the Pravyi Podhorenok River, Khabarovsk Territory, near the border with Primorye Territory (Fig. 2).
Within its range, the species tends to limestone outcrops, but can sometimes grow on slightly alkaline or neutral soil. The small area of habitats, the narrow ecological range of habitat conditions, and the relatively rare occurrence were the reasons for including $M$. schischkinii in the Red Data Book of Primorye Territory (Kozhevnikov 2008). Due to the stenotopic characteristics of the species, the weak competitive abilities, and the industrial development of its habitats (extraction of limestone), M. schischkinii has been given the conservation status of a vulnerable plant (VU). This species is not on the list of protected plants of Khabarovsk Territory, since its only locality was discovered there after the Red Data Book (Ishaev 2008) had been published.

The new locality of M. schischkinii on the right bank of the Bureya River is very remote $(480 \mathrm{~km})$ from the known
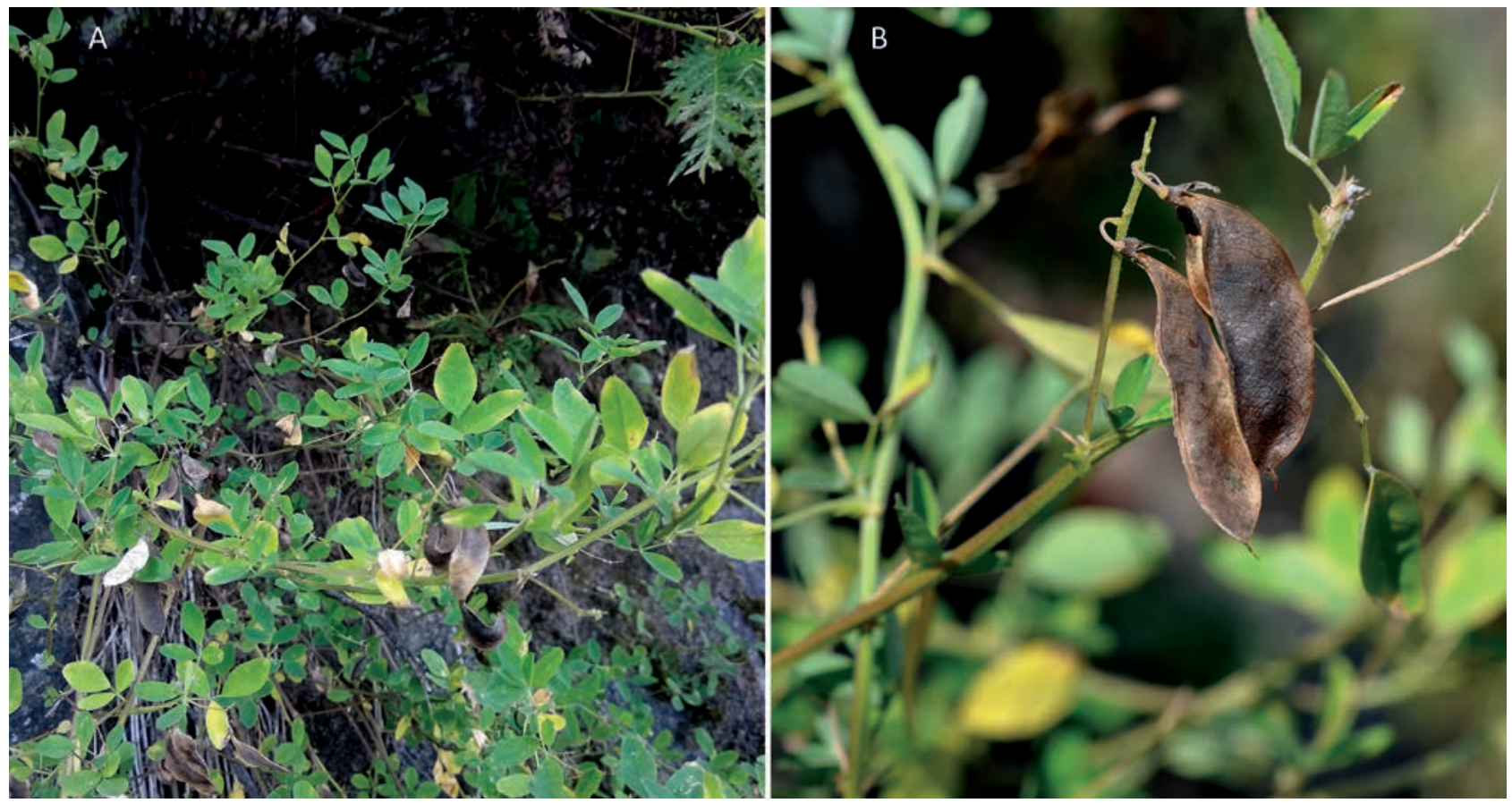

Figure 1 Melilotoides schischkinii (Vassilcz.) Soják in its habitat on the bank of Bureya River, Amur Region, 20.09.2018. A- general view, B - the infructescence. 


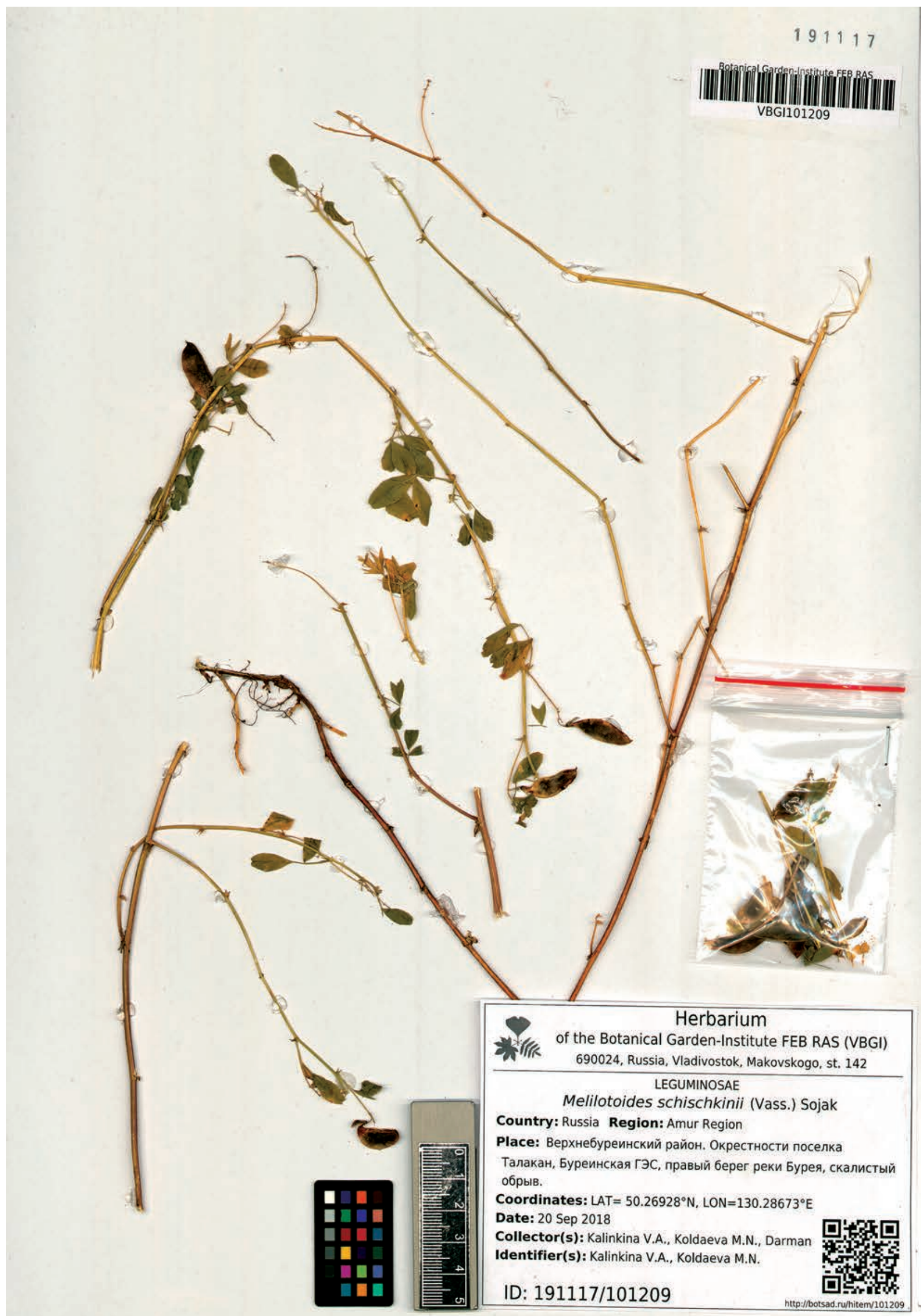

Figure 2 Voucher of Melilotoides schischkinii (Vassilcz.) Soják. Place: Verkhnebureinskii District, vicinity of town Talakan, Bureya hydropower station, right bank of Bureya River, rocky cliff. 
main range of the species (Fig. 3). All the earlier discovered localities of $M$. schischkinii were confined to the southern and central parts of the Sikhote Alin mountain system. For Amur Region and Jewish Autonomous Region, M. schischkinii has not been reported to date. Our finding substantially expands the known distribution range of this rare plant.

Below is a description of the habitat and conditions of the $M$. schischkinii coenopopulation found.

Amur Region, Bureya District, near Talakan Village, right bank of the Bureya River, $1500 \mathrm{~m}$ downstream of the Bureyskaya HPP $\left(50^{\circ} 26.346\right.$ 'N $130^{\circ} 29.173^{\prime} \mathrm{E}, 151 \mathrm{~m}$ alt.), September 20, 2018. Collected by M.N. Koldaeva, V.A. Kalinkina, and G.F. Darman (Amur Branch of the Botanical Garden-Institute, ABGI).

The coenopopulation is located on the high bank of the Bureya River and occupies the southeastern aspect of a rocky cliff with large cracked boulders. The found M. schischkinii was represented mainly by large generative individuals that were growing in cracks of rocks. The generative plants had numerous dangling shoots with rising tops. In addition to $M$. schischkinii, cracks and ledges of the cliff were overgrown by grass and shrub species typical for communities forming on rock outcrops, such as Allium maximoniczii Regel, Artemisia gmelinii Weber ex Stechm., A. selengensis Turcz. ex Bess., A. stolonifera (Maxim.) Kom., Aster maackii Regel, Bromopsis pumpelliana (Scribn.) Holub, Caragana manshurica (Kom.) Kom., Carex sp., Cystopteris fragilis (L.) Bernh., Dasiphora fruticosa (L.) Rydb., Eremogone juncea (Bieb.) Fenzl, Euonymus pauciflora Maxim., Heteropappus hispidus (Thunb.) Less., Philadelphus tenuifolius Rupr. et Maxim., Poa sp., Potentilla fragarioides L., Primula farinosa L., Pulsatilla cernua (Thunb.) Bercht. ex J. Presl, Rhododendron dauricum L., Valeriana fauriei Briq., Vicia amoena Fisch., Woodsia ilvensis (L.) R. Br., and green mosses.

Amur Region is located at the boundary between the Circumboreal and East Asian floristic regions (Tahtajan 1979, Krestov et al. 2005, Starchenko 2009). However, by characteristics of the flora, the Bureya River valley is referred rather to the East Asian floristic region. In the flora in the Bureya River valley, families Fabaceae (to which the found plant belongs), Lamiaceae, and Caryophyllaceae show a markedly increased species diversity and a significant coenotic role (Strachenko et al. 2015).

These families comprise a significant number of lightdemanding and drought-tolerant species with xeromorphic characters, tending to montane and rocky habitats (Galanin 1979, Khokhryakov 2000, Starchenko 2008). Along with the nemoral vegetation of zonal types, the increase in the number of xeromorphic species is partly a consequence of the historically formed transitory function of the Amur River valley. Species and communities of the continental steppe flora from northern China, Mongolia, Transbaikalia, and South Siberia penetrate into the forest zone across the Amur Valley. Similarly, xeromorphic species of steppe plants are distributed further along the major Amur tributaries, including the Bureya River.

As floristic studies show, the Bureya River valley appears to be a natural biogeographical boundary for many nemoral species (Starchenko et al. 2015) including our finding. The relatively small area of the Bureya Valley accommodates several endemic species, two of them, Saxifraga korshinskii Kom. and Taraxacum lineare Worosch. et Schaga are narrow local endemics to the Bureya Valley and are confined to the

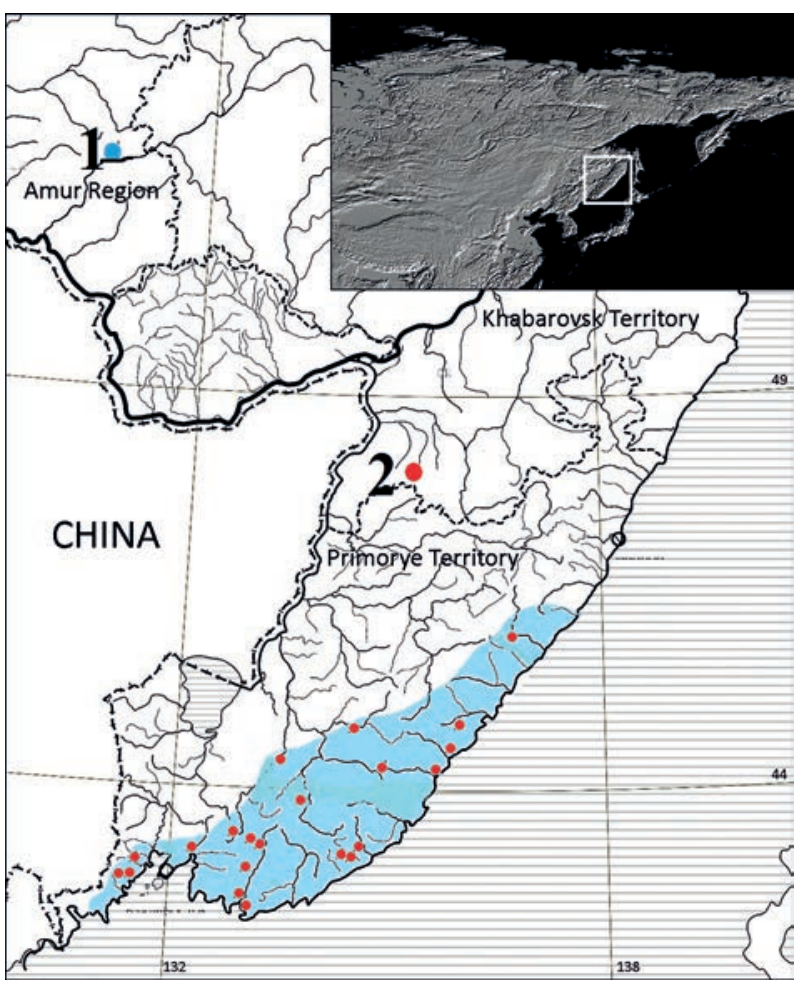

Figure 3 The range of Melilotoides schischkinii (Vassilcz.) Soják. 1 - new locality, 2 - the site of collection of M. schischkinii by M.V. Kryukova in Khabarovsk Teritory

humid rocks of the steep sides of the valley. All of them, including $M$. schischkinii, are a part of the rocky-stony complex, and this fact is emphasizes the significance of rock clif ecotopes as environmental refugia, and their significant role in the formation of the biological diversity of the territory.

This finding of a rare species new to Amur Region in the Bureya River valley is apparently not accidental. According to Starchenko et al. (2015), this area is characterized by a high level of biodiversity exposed to specific climatic, geographical, and orographic conditions. Moreover, this area hosts a high concentration of rare species, which determines its importance for solving biodiversity conservation issues.

\section{LITERATURE CITED}

Cherepanov, S.G. 1995. Vascular plants of Russia and neighboring countries (in the former USSR). "Mir i Semiya-95", St. Petersburg, 992 pp. (in Russian) [Черепанов С.Г. 1995. Сосудистые растения России и сопредельных государств (в пределах бывшего СССР). СПб: “Мир и семья-95". 992 с.]

Galanin, A.V. 1979. Ecotopological structure of the flora of Kurkure range (Eastern Altai). Botanicheskii Zhurnal 64(10):1401-1413 (in Russian with English abstract). [Taманин А.В. 1979. Экотопологическая структура флоры хребта Куркуре (восточный А^тай // Ботанический журнал. Т. 64, № 10. С. 1401-1413].

Grossheim, A.A. 1945. Trigonella. In: Flora of the USSR, vol. 11 (B.K. Schischkin, ed.), pp. 102-129, Izdatel'stvo AN SSSR, Moskva, Leningrad (in Russian). [Гроссгейм A.А. 1945. Trigonella L. / / ФАора СССР / поА реА. Б.К. Шишкина М.; А.: ИзА-во АН СССР. , Т. 11. С. 102-129].

Fabricii, Ph.C. 1763. Envmeratio methodica plantarvm. Litteris Ioannis Drimbornii, Helmstadii. 304 pp. 
Ishaev, V.I. (ed.). 2008. Red Data Book of the Khabarovsk Territory: rare and endangered species of plants and animals. Priamurskie vedomosti, Khabarovsk, 632 pp. (in Russian). [Kpacная книга Хабаровского края. Редкие и находящиеся поА угрозой исчезновения виды растений и животных / Ишаев В.И. (предс. реА. колмегии). 2008. Хабаровск: Приамурские ведомости. 632 с.].

Khokhryakov, A.P. 2000. Taxonomic spectra and their role in comparative floristics. Botanicheskii Zhurnal 85(5):1-11 (in Russian with English abstract). [Хохряков А.П. 2000. Таксономические спектры и их роль в сравнительной фмористике // Ботанический журнал. Т. 85, № 5. C. 1-11.]

Komarov, V.L. \& E.N. Klobukova-Alisova 1932. Key to plants of the Far Eastern Region of the USSR. AN SSSR, Leningrad. 1175 pp. (in Russian) [Комаров B.А., К^обукова-Алисова Е.Н. 1932. Определитель растений АаАьневосточного края. А.: АН СССР. 1175 с.].

Kozhevnikov, A.E. (ed). 2008. Red Data Book of Primorye Territory: Plants. Rare and endangered species of plants and fungi. AVK “Apel'sin”, Vladivostok, 688 pp. (in Russian). [Kpacная книга Приморского края: Растения. Редкие и находящиеся поА угрозой исчезновения виды растений и грибов / поА реА. А.Е. Кожевникова. 2008. ВАаАивосток: АВК «Апельсин». 688 с.].

Krestov, P.V., V.Yu. Barkalov, A.M. Omelko, V.V. Yakubov, Yu. Nakamura \& K. Sato 2005. Proposals to the floristic zoning of North Asia based on a comparative analysis of floras at the generic level. V.L. Komarov Memorial Lectures 51:15-56 (in Russian). [Крестов П.В., Баркалов В.Ю., Омелько А.М., Якубов В.В., Накамура Ю., Сато К. 2005. Предложения к флористическому районированию северной Азии на основе сравнительного анализа флор на родовом уровне // Комаровские чтения. Вып. 51. С. 15-56.]

Kryukova, M.V. 2013. Vascular plants of the Lower Amur. Dal'nauka, Vladivostok, 354 pp. (in Russian). [Крюкова М.В. 2013. Сосудистые растения Нижнего Приамурья. ВАадивосток: Аальнаука. 354 с.]

Lachashvili, I.Ya. 1958. On one forgotten genus (Melissitus Medik.). Trudy Tbilisskogo botanicheskogo instituta 19:3-29 (in Russian) [Аачашвили И.Я. 1958. Об одном забытом роде (Melissitus Medik.) / / Тр. Тбилисского ботанического института. Вып. 19. С. 3-29].

Ledebour, C.F. 1842. Medicago L. In: Flora Rossica, sive Enumeratio Plantarum in totius imperii Rossici, vol. 1, pp. 523-625, Sumtibus Librariae E. Schweizerbart, Stuttgartiae.

Linnaei, C. 1753. Species plantarum, vol. 2, pp. 561-1231. Impensis Laurentii Salvii, Holmiae.

Pavlova, N.S. 1989. Fabaceae. In: Vascular plants of the Soviet Far East, vol. 4 (S.S. Kharkevich, ed.), pp. 191-339, Nauka,
Leningrad (in Russian). [Павлова Н.С. 1989. Бобовые - Fabaceae // Сосудистые растения советского Аальнего Востока / отв. реА. С.С. Харкевич. А.: Наука. T. 4. C. 191-339.]

Pavlova, N.S. 2006. Fabaceae. In: Flora of the Russian Far East: Additions and changes to the publication "Vascular plants of the Soviet Far East". vols. 1-8 (1985-1996) (A.E. Kozhevnikov \& N.S. Probatova, eds), pp. 168-182, Dal'nauka, Vladivostok (in Russian). [Пав ова Н.С. 2006. Сем. Бобовые - Fabaceae // Фцора российского Аацьнего Востока: Аополнения и изменения к изданию «Сосудистые растения советского Аальнего Востока». Т. 1-8 (19851996). ВАадивосток: Аальнаука. С. 168-182].

Pimenova, E.A. 2016. Vascular plants. In: Plants, fungi and lichens of the Sikhote-Alin reserve (Pimenova E.A., ed.), pp. 172-365, Dal'nauka, Vladivostok (in Russian with English abstract). [Пименова Е.A. 2016. Сосудистые растения // Растения, грибы и мишайники СихотэА^инского заповедника / под реА. Е.А. Пименовой. ВАаАивосток: Аальнаука. С. 172-365].

Starchenko, V.M. 2008. Flora of the Amur Region and the issues of its protection: the Far East of Russia. Nauka, Moscow. 228 pp. (in Russian). [Старченко B.M. 2008. ФАора Амурской области и вопросы ее охраны: Аальний Восток России. М.: Наука. 228 с.].

Starchenko, V.M. 2009. Taxonomic analysis of the aboriginal flora of Amur Oblast. V.L. Komarov Memorial Lectures 56:152-169 (in Russian). [Старченко B.M. 2009. Таксономический анализ аборигенной фморы Амурской области // Комаровские чтения. Вып. 56. ВАадивосток: Аальнаука. С. 152-169.]

Starchenko, V.M., G.F. Darman \& I.G. Borisova 2015. Flora of the Bureya River Valley (Amur Oblast). V.L. Komarov Memorial Lectures 63:69-98 (in Russian). [Старченко B.M., Аарман Г.Ф., Борисова И.Г. 2015. ФАора Аолины реки Буреи (Амурская область) // Комаровские чтения. Вып. 63. ВАадивосток: Аальнаука. С. 69-98].

Tahtajan, A.L. 1978. Floristic Regions of the Earth. Nauka, Leningrad, 248 pp. (in Russian). [Тахтаджян A. 1.1978. Фцористические области Земли. А.: Наука. 248 с.].

Vassilchenko, I.T. 1951. Trigonellae generis species et sections nova. Notulae Systematicae ex Herbario institute Botanici Nomine V.L. Komarovii Academiae scientiarus URSS 14:229_ 235 (in Russian). [Васильченко И.Т. 1951. Новые виды и секции рода пажитник // Ботанические материалы гербария Ботанического института им. В.А. Комарова. Т. 14. С. 229-235].

Voroschilov, V.N. 1966. Flora of the Soviet Far East. Nauka, Moscow. 477 pp. (in Russian). [Ворошилов B.H. 1966. ФАора советского Аальнего Востока. М.: Наука. 477 с.]. 